\title{
Application of Wastewater in the Frame of Circular Economy; Irrigation of Agricultural Lands
}

\author{
Rita Kendrovics -Boda ${ }^{*, 1}$, Imre L. Biczó ${ }^{~}$ and Zoltán Juvanc ${ }^{1}$ \\ ${ }^{1}$ Environmental Institute of Rejtő Sándor Faculty of Light Industry and Environmental Protection Engineering, Óbuda University, Hungary
}

\begin{abstract}
A great number of examples for Circular Economy applications are knonw in the field of solid, recyclable waste treams. In this area a massive development can be adsorbed. Relativly fewer efforts are devoted to the reuse of liquid resources. But waste water treatment is a technology what could be also considered as a technology what is able to provide streams otherwise problematic and not valorized: nutrients for agricultural use. An example for that new concept is the reuse of waste water for irrigation. This application can reduce the water scarcity and so slow down the increasing demand for fesh and absolutely clean water.

The reuse of treated waste water could create the opportunity of an integrated water management and so could contribute to the management of lack of water, and sustainable use of water resources. To apply this new approach the way of thinking should be changed according to the goals and action plan of EU "Circular Economy".

One of the key concepts of the integrated water management is to reuse the retained materials, - to the greatest extent-, materially or energetically. In this process the waste water treatment could be reshaped to avoid the environmental contamination and the depletion of natural resources in the same time: This approach needs to have relevant technical and institutional backgrounds and need to be economically viable and socially accepted.

The reuse for irrigation of the cleaned waste water could contribute to the saving of water resources in areas where the lack of water and use of groundwater create an important problem or the effective water management is in danger. This application of waste water for irrigation should be realized through living ecosystems; parks, lakes and ponds, wetland systems, forests and orchards. The paper highlights the technological opportunities and regulation background of reuse of treated waste water for irrigation according to the above mentioned ideas.
\end{abstract}

Keywords: waste water recycling, circular economy, integrated water management, reuse of waste water for irrigation.

\section{Introduction}

Water scarcity is one of the most important global problems what concerns almost all societies in the World in the 21 th century. Almost $20 \%$ of the population of the World is living on areas where they have to face physical scarcity, while $1 / 4$ of the global population faces economical scarcity. Latter means lack of proper infrastructure for exploitation of either surface or groundwater resources [1].

The climate change, due the increasing greenhouse gases $\left(\mathrm{CO}_{2^{\prime}} \mathrm{CH}_{4^{\prime}} \mathrm{N}_{2} \mathrm{O}\right)$ emission, - makes this situation even worse [2].The climate change intensifies the water cycle, the evaporation.

It is forecasted that $60 \%$ of population will be living in cities by 2030 out of the more than the 8 billion people. 
This projected fact will change the ecosystem and the environment. [3].This urbanization will cause a massive increase in waste generation and energy-demand and the problems associated with waste and rain water treatment.

The growing population and the climate change result in the growing demand for water. The traditional water management is changing due to the water scarcity and due to the competitive situation for water resources. Today water management includes the non-conventional water resources also as for example the low yield wells, rainwater management and reuse of waste water [1].

The agriculture is one the biggest water users; irrigated cultivation is accountable for $70 \%$ of fresh water use [4].

It can be said due to this fact that water scarcity could be solved by effective use of our water resources, the water-saving irrigation technologies and reuse of waste water. Although we can observe water wasting activities both in Europe and in Hungary but we can also see the signs of paradigm shift. One example of this change is the press release of the European Commission on the Circular Economy Package published on the $17^{\text {th }}$ of March in 2016 [5]. With this new approach European Commission boosts the use of organic and waste-based fertilizers. One of the main goals of this measure is to make possible the reuse of the bio-waste converted into raw materials what can be used to manufacture fertilizing products.

The goals outlined in the action plan support the actuality of reuse of waste water especially in the field of agriculture. This application will have a growing importance in the future mainly in arid, droughty areas. In these areas the waste water is considered not only as soil nutrient but also as soil humidity improver. Taking into account the topographical and climate aspects it can be stated that the reuse of waste water after sufficient purification has a positive effect on the water management of those arid agricultural lands. Shortly we can state that the used water should be considered not as waste what is needed to discharge but this amount of water, - what was costly cleaned before its use, - should be retained and used for irrigation.

This paper outlines the requirements relating to and opportunities of reuse of waste water for irrigation.

\section{The necessity, opportunities and limitations of reuse of waste water}

In the light of the above written statements the waste water should be considered as a source of water what is available in the given area and time. The water is the source of the life so, - according to the Circular Economy approach-, the modern water management should focus on the whole water cycle as a challenge.

In the Circular Economy the (raw) materials and energy flow in a closed-loop where the resources are (re)used in an effective way so the ecological footprint is decreased and the application of clean technologies and clean production is getting more important. (Fig.1.)

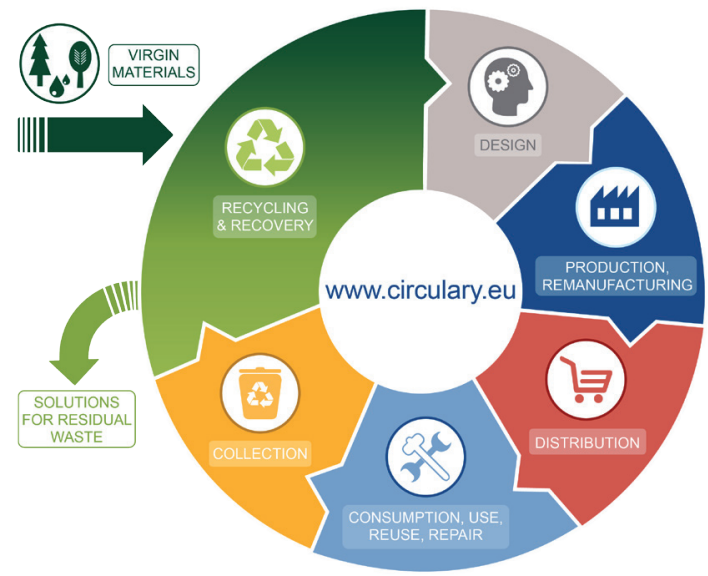

Fig. 1: Circular Economy. (http://www.aisec-economiacircolare.org/wpcontent/uploads/2018/08/circular_economy_Icon-EN-New-final-01.png)

The concept of Circular Economy can be applied in the field of water management also. In this case the reuse of the appropriately cleaned waste water and waste water sludge get importance. The safe and cost-effective reuse of the appropriately cleaned waste water is a valuable solution of water managemet what is not applied in high scale for the time being. Although this could be a solution towards the better use of water resources and better water supply. This approach is known as "integrated water management". in the frame of this approach the cleaned waste water should be kept and reused in the area where it was used. In this way both the water recipient could be less charged and meantime the nutrients what can be found in the 
waste water could be utilized. The EU action plan for the circular economy underlines the necessity of the legislation as an important task; "The Commission will take a series of actions to promote the reuse of treated wastewater, including legislation on minimum requirements for reused water." [7]

\subsection{Opportunities of Waste Water Reuse}

The reuse of waste water means the use of water what is generated during the waste water treatment and meats the quality requirements of the given application purposes. The quality requirements include; health and environmental risk mitigation measures, national and European relevant legislation. The reuse of properly treated waste water can be direct; from the waste water treatment plant the treated water could be pumped directly into the pipe system. Or this application could be indirect; the of properly treated waste water first is descharged into a natural water recipient; a river or a lake fromwhere later would be pumped out for irrigation for example.

The reuse of properly treated waste water means the recycling of the nutrients of the treated waste water and one of the water itself. The reuse of waste water can save partly or totally the original water resources in the following areas;

$\checkmark$ in case of the application of highly effective drinking water treatment technologies the reuse of waste water can contribute to drinking water production,

$\checkmark$ recharge of groundwater reservoirs,

$\checkmark$ for agricultural, industial and urban purposes, if the drinking water quality is not rtequired,

$\checkmark$ furtehrmore the sludge generated by the waste water treatment processes can be used for agricultural or energetic applications.

The reuse of waste water is allowed in some countries for direct or indirect drinking water supply.

\subsection{The necessity of reuse of waste water - the effects of climate change on water resources}

There is no doubt about the climate change and the effect of greenhouse gases is not questioned neither.

The climate change used to be a natural phenomena over the history of the Earth buti in geological times those natural changes had happened over longer period of the time. The use of fossil fuel in the energy creation has been increased by $33 \%$ since the Industrial Revolution. The following figure shows the global $\mathrm{CO}_{2}$ emission.

Higher the $\mathrm{CO}_{2}$ concentration in the atmosphere

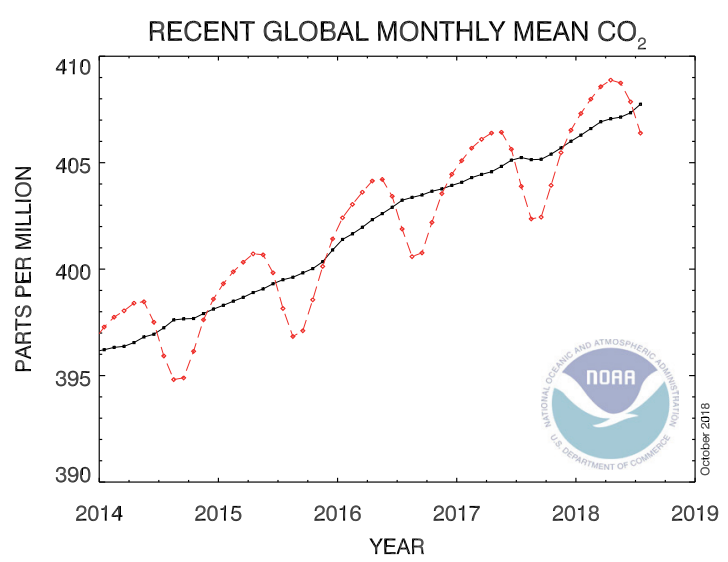

Fig. 2: $\mathrm{CO}_{2}$ emission WW. (http://www.esrl.noaa.gov/gmd/ccgg/trends/ global.html)

grater the climate change. The growing average temperature accelerates the local and global water cycle; evaporation, precipitation, falling, infiltration, run-off. This results in a grater average precipitation by $3,9 \%$ compering to the average of the years 60 90 s.

The climate models prognosticate the further growth of the of avarege precipitation. The intensity of the fall and winter precipitation will be even higher while the summer rainfalls will decrease and the dry seasons will be longer due to the climate change model forecasts.

The presipitation shift can be demonstrated by the followinh Hungarian data; The rain fall varied between 14 - $188 \mathrm{~mm}$ in May 2017, while the average was $51 \mathrm{~mm}$. This average was smaller by 15\% (i.e. $9 \mathrm{~mm}$ ) than the referenc data measured between 1971 and 2000, due to the data measured by the General Directorate of Water Management.

The water management faces big chalanges because the warming and longer dry periods and the intensive rain falls are disadvantageous for the water resources. The water run-offs are decreasing by $10-20 \%$ due to the modell calculations, especially in the Eatern part of the country. The degradation of the surface water balance causes decreasing infiltration of the water so the recharge rates of the smaller watercourses, streams and small rivers are decreasing also.

The frequency and the extention of the period of drought in Hungary are supposed to grow due to the climate change. This change is provoked by higher summer average temprerature and the growing number of hot days. The lack of summer 
Tab. 1: Reuse of waste water by application areas and necessary teratments US EPA.

\begin{tabular}{|c|c|c|c|}
\hline \multicolumn{2}{|c|}{ Water reuse } & \multirow[b]{2}{*}{\begin{tabular}{l}
\multicolumn{1}{c}{ Teratment goals } \\
Secondary filtration, \\
disinfection \\
BOD $_{5} \leq 10 \mathrm{mg} / \mathrm{l}$ \\
Turbidity: $\leq 2 \mathrm{NTU}$ \\
Fecal coliform: $0 / 100 \mathrm{ml}$ \\
$\mathrm{Cl}_{2}$ residual: $1 \mathrm{mg} / \mathrm{l}$ \\
$\mathrm{pH} 6-9$
\end{tabular}} & \multirow[b]{2}{*}{$\begin{array}{l}\text { Example of applications } \\
\text { LAndscape irrigation } \\
\text { (parks, palygrounds, school } \\
\text { yards, fire protection, } \\
\text { ornamental fountains, in- } \\
\text { building uses (toalets, air } \\
\text { conditioning) }\end{array}$} \\
\hline \multirow[b]{2}{*}{ Urban use } & Unrestricted & & \\
\hline & Restricted & $\begin{array}{l}\text { Secondary and } \\
\text { disinfection } \\
\mathrm{BOD}_{5} \leq 30 \mathrm{mg} / \mathrm{l} \\
\mathrm{TSS}^{*} \leq 30 \mathrm{mg} / \mathrm{l} \\
\text { Fekál koliform: } \leq 200 / 100 \\
\mathrm{ml} \\
\mathrm{Cl}_{2} \text { residual: } 1 \mathrm{mg} / \mathrm{l} \\
\mathrm{pH} 6-9\end{array}$ & $\begin{array}{l}\text { Irrigation of areas where } \\
\text { public access is infrequent } \\
\text { and controlled } \\
\text { (golf courses, cemeteries) }\end{array}$ \\
\hline \multirow{2}{*}{ Agricultural irrigation } & Food crops & $\begin{array}{l}\text { Secondary filtration, } \\
\text { disinfection } \\
\mathrm{BOD}_{5} \leq 10 \mathrm{mg} / \mathrm{l} \\
\text { Turbidity: } \leq 2 \mathrm{NTU} \\
\text { Fecal coliform: } 0 / 100 \mathrm{ml} \\
\mathrm{Cl}_{2} \text { residual: } 1 \mathrm{mg} / \mathrm{l} \\
\mathrm{pH} 6-9\end{array}$ & $\begin{array}{l}\text { Crops grown for human } \\
\text { consumption and } \\
\text { consumed uncooked }\end{array}$ \\
\hline & $\begin{array}{l}\text { Non-food crops and food } \\
\text { crops consumed aftre } \\
\text { processing }\end{array}$ & $\begin{array}{l}\text { Secondary and } \\
\text { disinfection } \\
\mathrm{BOD}_{5} \leq 30 \mathrm{mg} / \mathrm{l} \\
\mathrm{TSS} \leq 30 \mathrm{mg} / \mathrm{l} \\
\text { Fecal coliform: } 200 / 100 \mathrm{ml} \\
\mathrm{Cl}_{2} \text { residual: } 1 \mathrm{mg} / \mathrm{l} \\
\mathrm{pH} 6-9\end{array}$ & $\begin{array}{l}\text { Fodder, fiber, seed corps, } \\
\text { commrecial acquaculture }\end{array}$ \\
\hline \multirow{2}{*}{ Recreational use } & Unrestricted & $\begin{array}{l}\text { Secondary filtration, } \\
\text { disinfection } \\
\mathrm{BOD}_{5} \leq 10 \mathrm{mg} / \mathrm{l} \\
\text { Turbidity: } \leq 2 \mathrm{NTU} \\
\text { Fecal coliform: } 0 / 100 \mathrm{ml} \\
\mathrm{Cl}_{2} \text { residual: } 1 \mathrm{mg} / \mathrm{l} \\
\mathrm{pH} 6-9\end{array}$ & $\begin{array}{l}\text { No limitation on body } \\
\text { contact (lakes, and ponds } \\
\text { used for swimming, } \\
\text { snowmaking) }\end{array}$ \\
\hline & Restricted & $\begin{array}{l}\text { Secondary and } \\
\text { disinfection } \\
\text { BOD }_{5} \leq 30 \mathrm{mg} / \mathrm{l} \\
\text { TSS: } \leq 30 \mathrm{mg} / \mathrm{l} \\
\text { Fecal coliform: } 200 / 100 \mathrm{ml} \\
\mathrm{Cl}_{2} \text { residual: } 1 \mathrm{mg} / \mathrm{l} \\
\mathrm{pH} 6-9\end{array}$ & $\begin{array}{l}\text { Fishing, boating and other } \\
\text { noncontact recreational } \\
\text { activities }\end{array}$ \\
\hline \multicolumn{2}{|c|}{ Environmental enhancement } & $\begin{array}{l}\text { Similar to unrestricted } \\
\text { urban uses } \\
\text { Disolved oxygen; } \mathrm{pH} ; 6-9 \text {, } \\
\text { Coliform organisms, } \\
\text { nutrients }\end{array}$ & $\begin{array}{l}\text { Artificial wetlands, } \\
\text { enhanced natural wetlands } \\
\text { and sustained strem flows }\end{array}$ \\
\hline \multicolumn{2}{|l|}{ Grandwater recharge } & site-specific & $\begin{array}{l}\text { GRaoundwater } \\
\text { replenishment,salt water } \\
\text { intrusion control }\end{array}$ \\
\hline \multicolumn{2}{|l|}{ industrial reuse } & $\begin{array}{l}\text { Secondary, disinfection } \\
\text { BOD }_{5} \leq 30 \mathrm{mg} / \mathrm{l} \\
\text { TSS: } \leq 30 \mathrm{mg} / \mathrm{l} \\
\text { Fecal coliform: } 200 / 100 \mathrm{ml}\end{array}$ & $\begin{array}{l}\text { Cooling system makeup } \\
\text { water, process waters, } \\
\text { boiler feed waters }\end{array}$ \\
\hline \multicolumn{2}{|l|}{ Potable } & $\begin{array}{l}\text { Meet requirements for safe } \\
\text { drinking water }\end{array}$ & $\begin{array}{l}\text { Blending with municipal } \\
\text { water supply }\end{array}$ \\
\hline
\end{tabular}

*TSS-total suspended solids

precipitation and the whether extremes further aggravate the situation.

Nowadays it can be stated that $35 \%$ of the area of Hungary belongs to the especially highly vulnerable zones due to the droughty periods caused by climate change. $22 \%$ of the Hungarian population is leaving in these micro-regions what represent about $45 \%$ of the most marginalized areas.

Taking into account those tendencies and the growing ratio of arid areas in the future (Fig.3.) it is evident that it is a must to deal with the reuse of the waste water.

It is a fundamental principle that the approriatly cleaned wastewater should be kept in the micro- 


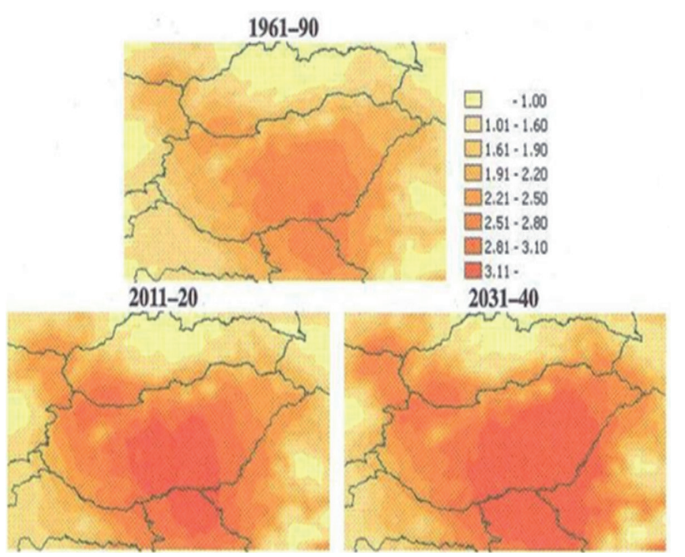

Fig. 3: The growth of aridity in Hungary (presented by B. Nováky $B$ at a Conference on "Future building" 2008).

region where it was generated. The reuse of this wastewater could be realised by either infiltration into the soil or irrigation. This approach is in line with the Directive of the Council of the European Communities (91/271/EEC) as it is stated in article 12 (1); „Treated waste water shall be reused whenever appropriate. Disposal routes shall minimize the adverse effects on the environment." On the base of this Directive the reuse of the appropratly cleaned waste water is an important goal to be supported int he period of 2014- 2020. The reuse could ment groundwater recharge, irrigation, pond-farming on recultivated areas. To reach these goals we need to change our mindset furtehrmore a system of supportive measures should be introduced and applied.

The reuse of appropriatly cleaned waste water could make possibe to create a more competitive agriculture in Hungary. This new appraoch could decrease the dependence of teh agriculture on rain water and water resources. Applying the waste water for irrigation the land used for agriculture could be bigger by 5-10\%. Actually the irrigated agricultuiral area in Hungary currently is $0-3 \%$ which is far below the average European Union (5,8\%). The water what is used for irrigation mostly (90\%) comes from surface water sources.

\subsection{Limitation for the use of the waste water}

The requirements relating to the waste water use are as follow;

$\checkmark$ human health protection; concentration limits should be identified both for pollutants and pathogenic agents,

$\checkmark$ protection of the soil and plants; limits for heavy metals and salts must be kept, $\checkmark$ groundwater protection; pollutant limits must be kept, $\checkmark$ acceptance of this technology by people and by authorities, $\checkmark$ the opportunities for waste water storage before irrigation.

If the firts two from the list above are kept and have kept the last requirement is easier to be met. To have a system approache the general legislative framework and detailed techical regulation inculding the acceptable limits must be in place.

Although the above listed reuirements for the reuse of waste water are known in some countries (e.g.; Turkey, Tunisia, and Mexico) untreated waste water is used for irrigation of agricultural lands. In other areas the relating rules are very strict, e.g. in California, the tertiary treatment is also required for the reuse of the waste water.

The relativly new tests revealed a new type of limitation for the reuse of waste water; these are trace chemical compunds as residues of of PhACs-Pharmaceutically Active Compounds, PCPsPersonal Care Products. These chemicals represent a health risk and called together as EDC-Endocrin Distrupting Chemicals because they are harmful for the endocrin system. To evaulate the risk of these chemicals further investogations and test will be needed. Perhaps additional treatment proceedures must be applied to avoid health risks. A grater emphasis on the development of waste water treatment technologies should be used to improve the effecvtivness of the removal of the organic micro pollutants. Such so called fourth level waste water treatment technologies are already used in Heirsau (Switzerland) and in UIm (Germany). These promising technologies make possible to remove the above mentioned micro pollutants.

Further considerations to be taken into account relating to the waste water use in agricultiure are as follow;

$\checkmark$ the irrigation with tretead waste water might cause odours; to avoid this problem a given detection distance msut be established and controled for the opperations,

$\checkmark$ the soil caracteristics could be changed in case of wronlgy applied irrigations, the soli must be monitored,

$\checkmark$ to avoid bactreial pollution additional (pre)treatment should be applied.

On the base of the above listed requirements and considerations it can be stated that the adequate treatment of the waste water must be carried out prior the reuse of the waste water. To determine the parameters of the "adequate treatment" both the characteristics of waste water pollutants and the 
soil and the plants to be irrigated must be know. To know the efficiency of the treatment technologies to be applied is also inevitable. To know the selfrecuperative power is also important to be able to determin the permissible limits of the waste water charge. This is depending on the soil thikness. If these parameters are not taken into account the groundwater could be polluted and so the drinking water resources also. This is the reason why the limits for the listed parameters in the Governement Decree 50/2001 (IV.3.) must be met.

The above detailed requriements provoke a prudent and reasonable planning and implementation of irrigation. This approach must be established on analytical results.

\section{Reuse of waste water for agricultural purposes}

The ratio of the reuse of the waste water between agriculture and other purposes mostly is shifted towards the former one. These ratios are shown in case of countries where the fresh water scarcity is a problem on figure 4.

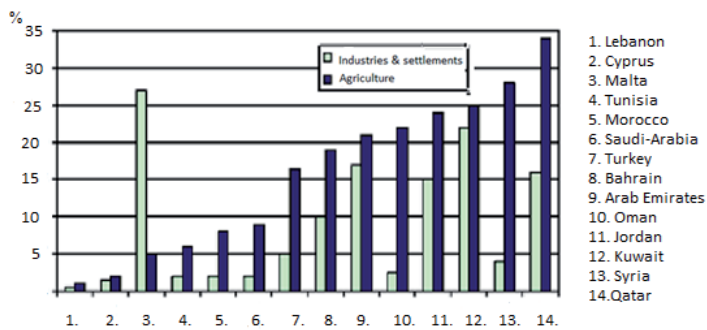

Fig. 4: The ratio [\%] of the reuse of the waste water in different countries facing fresh water scarcity.

\subsection{The source and quality of the waste water}

The urban waste water is generally suitable for irrigation purposes after appropriate treatment. The treatment must address the pathogenic microorganisms and mainly the requirements of the Public Health Code must be met.

In case of industrial waste water sources only those could be used for agricultural irrigation what contain mainly natural, biodegradable, organic pollutants. If this type of waste water contains toxic pollutants these msut be below the relevant limits. Waste waters from the food industry, mainly from the sugar-, canning-, starch-, spirits-, beer-, beverage- and dairy industry are the most suitable. Waste waters from the light industrial activities are also usable for irritation e.g. paper-, pulp-, wood industry. The waste water streams from the chemical industry mostly not suitable for irrigation but the waste water of the fertilizer production could be beneficial as this type of waste water practically could be considered as watery fertilizer solutions. The waste water generated by the energy sector by cooling processes and the waste water the building sector could be also used for irrigation in the agriculture if the quality requirements. are met. The agricultural waste water is mostly applicable for irrigation also except their pollutants limits the applications.

Obviously the waste water what contains pollutants as toxic or radioactive ones above the acceptable limits is not usable.

The national regulation classifies the usability of the waste water for irrigation according to hygienic criteria as follow;

$\checkmark$ The waste water what does not contain toxic, harmful or radioactive materials can be used withouth restictions. This waste water must be collected separately from urban waste water. Furthermore the waste water of food industries is also usable without restictions if fecal contamination can be disclosed.

$\checkmark$ Urban and industial waste water can be used for agricultural irrigation with restriction if pathogen microbes can be present, but toxic or radioactive pollutants are certainly below the acceptable limits.

$\checkmark$ The waste water type what contains toxic or radioactive pollutants, - even one pollutant as such-, above the acceptable limits can not be used for irrigation in the agriculture. Similarly waste water from institutions where human or animal infectious diseases can occure can not be used for irrigative purposes.

The relevant Hungarian legislation specifies the proceedures of soil investigation and the authorization processes addressing questions of the higenie, water quality, animal health care and environmental concerns.

\subsection{Natural constraints}

The self-cleaning capability of the ecosystems makes possible the reuse of the acceptably treated waste water.

To let the natural process happen we need appropriate soil layer and time. If one of these elements is missing the soil and/or the groundwater will be polluted by pathogen micro-organisms and/ or organic pollutants. Different soil types can "clean" and tolerate different waste water pollutants but always only up to a given loading level.

So the toxic and salt content will determine the 
usability of a given waste water for agricultural irrigation purpose.

\subsection{The specific waste water quantity}

The appropriately cleaned waste water is a source of water, nutrient, organic material so it is important for the growth of the plants. It is very important that the effect of the irrigation water (waste water) on the water regime and on the biogeochemical cycle of the nutrients must be considered. To calculate the maximum quantity of the waste water to be used for irrigation yearly on a given piece of land the following aspects must be considered;

$\checkmark$ the water balance of the given area, the excess water quantity must be drained elsewhere,

$\checkmark$ it is important to avoid the accumulation of different salts in the root zone,

$\checkmark$ the organic load of the irrigating water must be balanced with the biodegradation capability of the irrigated area,

$\checkmark$ similarly the nutriant content must be in balance with the nutriant demand of the irrigated plants

$\checkmark$ the load of the toxic components must be kept below the acceptable limits.

\subsection{The grown crop}

The folloving plants could be irrigated most effectively with the treated wastewater;

\section{$\checkmark$ reedy, grassy areas, \\ $\checkmark$ areas of natural vegetation and forest plantations e.g. poplar, willow, \\ $\checkmark$ energy crops, biomass production, \\ $\checkmark$ arable farming; corn, sugar beet, sunflower, \\ $\checkmark$ vineyards, orchards.}

The tree plantations (poplar and willow) are the most suitable for the economic and environmental friendly treatment of waste water.

It is important to build temporary waste water storage for the periods where there is not vegetation, no need for irrigation e.g. in case of arable farming.

\subsection{The Hungarian experience relating to agricultural reuse} of waste water

The reuse of waste water for agriculural purposes, mainly as irriagtion water started already in the 1920s in Hungary. In this time the waste water was used for irrigation and in fish ponds in seven areas; around the following cities; Debrecen, Sopron, Pécs, Eger, Székesfehérvár, Kaposvár and Budapest. Unfortunatelly the overuse of waste water caused public health problems in some cases. Scientific research of and experimental irrigation with waste water has been started in Debrecen in the 60s.

The folowing two tables (table 2 and 3 ) summarize the experimental parameters of 12 urban and 6 industrial waste water treatment plants.

Although the results clearly showed the benefits of the reuse of waste water for irrigation but due to the changing environment and regulation and acceptance of the neighborhood the experiments started in the 60s-70s were stopped int he 80s. This change was supported by changing structure of agricultural landlords also.

There are still some poplar plantations (about 1620) where treated waste water is used for irrigation, but their weight is not too significant.

On the other hand there are about 4-6 new sites where treated waste water is used again for irrigation. These sites has been in operation since the early 2000s and mostly polplar plantations.

The other areas where the approprietly treated waste water is getting more and more used are the energy crop production and biomass farming.

\subsection{Waste water reuse for irrigation of energy crops cultures}

The environmental, climate and soil capabilities of Hungary make possible to build a biomass industry. One of the key activity toward this goal is to production of energy crops. And the energy crop farming gives a great oportunity for the utilisation of treated waste water for irrigation! In case of the woody energy crops one of the limitation factors of biomass production is the lack of water. So this make understandable the importance of the utilisation of treated waste water for irrigation trhough the whole year. Ont he other hand the cultivation of the woody energy crops can be considered as waste water treatment technology also. So this activity has a double goal; on one hand thosn is energy, biomass production ont he other hand this is a further treatment of waste water and irrigation int he same time. And the third advantage of this technology is that with this application we can use less valuable agricultural lands for production, this could be considered as a bronw field investment also. Some species of woody energy crops take up extremly high amount of $\mathrm{N}$ and $\mathrm{P}$ from the terated waste water so those species are even more effective in the final treatment of the waste water.

According to the new "National Energy Strategy 2030" of Hungary the biomass production and so the cultivation of energy crops gets more and more importance. So the teh woody energy crops will be an important source of renewable energy and int he same time this will create more opportunity for the reuse of waste water. 
Tab. 2: Experimental urban waste water sites where treated waste water was used for agricultural irrigation.

\begin{tabular}{|c|c|c|c|c|c|c|}
\hline \multirow[b]{2}{*}{ SettIment } & \multirow[b]{2}{*}{ Treatment } & \multirow[b]{2}{*}{ Recipient } & \multirow[b]{2}{*}{$\begin{array}{l}\text { Capacity } \\
{\left[\mathrm{m}^{3} / \mathrm{d}\right]}\end{array}$} & \multicolumn{3}{|c|}{ Area [ha] } \\
\hline & & & & $\begin{array}{l}\text { arable } \\
\text { land }\end{array}$ & forest & total \\
\hline Kecskemét & \multirow{2}{*}{$\begin{array}{l}\text { mechanical } \\
\text { pretreatment+irrigation }\end{array}$} & $\begin{array}{l}\text { Kiskunfélegyházi- } \\
\text { canal }\end{array}$ & 18000 & 761 & 76 & 837 \\
\hline Cegléd & & $\begin{array}{l}\text { Cigányszéki } \\
\text { irrigation ditch }\end{array}$ & 5600 & 800 & 50 & 850 \\
\hline Gyula & $\begin{array}{l}\text { mechanical } \\
\text { pretreatment+ trickling } \\
\text { filtration+irrigation }\end{array}$ & Kétegyházi canal & 7600 & - & 140 & 140 \\
\hline Nyírbátor & \multirow{9}{*}{$\begin{array}{l}\text { mechanical } \\
\text { pretreatment+irrigation }\end{array}$} & \multirow{9}{*}{ soil } & 2400 & - & 50 & 50 \\
\hline Zalakaros & & & 1000 & - & 36 & 36 \\
\hline Nagykálló & & & 500 & - & 18 & 18 \\
\hline Agárd & & & 300 & - & 10 & 10 \\
\hline Hőgyész & & & 300 & - & 10 & 10 \\
\hline Székkutas & & & 350 & - & 16 & 16 \\
\hline Füzesgyarmat & & & 120 & - & 6 & 6 \\
\hline Kisléta & & & 10 & - & 4 & 4 \\
\hline Mezőkovácsháza & & & 50 & - & 10 & 10 \\
\hline Total & & & 35520 & 1561 & 426 & 1987 \\
\hline
\end{tabular}

Tab. 3: Experimental industrial waste water sites where treated waste water was used for agricultural irrigation.

\begin{tabular}{|c|c|c|c|c|c|c|}
\hline \multirow[b]{2}{*}{ Industrial site } & \multirow[b]{2}{*}{ Treatment } & \multirow{2}{*}{$\begin{array}{l}\text { Start of } \\
\text { operation }\end{array}$} & \multirow{2}{*}{$\begin{array}{l}\text { Capacity } \\
{\left[\mathrm{m}^{3} / \mathrm{d}\right]}\end{array}$} & \multicolumn{3}{|c|}{ Area [ha] } \\
\hline & & & & $\begin{array}{l}\text { arable } \\
\text { land }\end{array}$ & $\begin{array}{l}\text { arable } \\
\text { land }\end{array}$ & összes \\
\hline $\begin{array}{l}\text { Szigetvár } \\
\text { Cannery }\end{array}$ & $\begin{array}{l}\text { mechanical } \\
\text { pretreatment+irrigation }\end{array}$ & 1970 & 6000 & - & 98 & 98 \\
\hline $\begin{array}{l}\text { Bácsbokodi } \\
\text { Dairy }\end{array}$ & $\begin{array}{l}\text { mechanical } \\
\text { pretreatment+irrigation }\end{array}$ & 1974 & 350 & 22 & 2 & 24 \\
\hline Borsodi Brevery & $\begin{array}{l}\text { mechanical } \\
\text { pretreatment+irrigation }\end{array}$ & 1975 & 8000 & 604 & 88 & 692 \\
\hline Sarkadi Sugar Factory & ponds & $1975-78$ & 6700 & - & 50 & 50 \\
\hline $\begin{array}{l}\text { Répcelaki Cheese } \\
\text { Factory }\end{array}$ & $\begin{array}{l}\text { mechanical \& chemical } \\
\text { pretreatment+irrigation }\end{array}$ & 1980 & 510 & 76 & 18 & 94 \\
\hline $\begin{array}{l}\text { Hernádi Poultry } \\
\text { Processing }\end{array}$ & $\begin{array}{l}\text { oxidation }+ \\
\text { sedimentation }+ \\
\text { irrigation }\end{array}$ & 1981 & 1400 & - & 22 & 22 \\
\hline \multicolumn{3}{|r|}{ Total } & 22960 & 702 & 278 & 980 \\
\hline
\end{tabular}

\section{Summary}

To accelerate the development of strategically important reuse of appropriatly terated waste water the social, economical and environmental aspects must be taken into account.

The most sensitive element of this desition making process is the social acceptance of irrigation with waste water. Probably the reuse of waste water should be considered as "new water" to make the acceptance easier.

Obviously the use of this "new water" must be implemented after a serious risk assessment in each cases. The relevant legislation with the limits and authorization processes must be layed down in line with the EU directives. The regulation must address the responsabilities of each player of the process to make relaible the operation of the reuse of waste water. The social acceptance can be raised by the information dissemination e.g. the results of analitical quality measurements of pollutants int he irrigation water.

Improving the application opportunities of waste water for irrigation we can have the following benefits;

$\checkmark$ contirbution to realization of the national environmental goals,

$\checkmark$ development of agricultural production and biomass industry, $\checkmark$ job creation for people working in the waste water treatment and biomass sectors,

$\checkmark$ keeping the (used) water in the regions,

$\checkmark$ improved landscaping,

$\checkmark$ in case of water scarcity ther will be additional water source 
(new water),

$\checkmark$ using waste water for irrigation the nutriantts / pollutant content will be utilised and int he same time mean less environmental burden for the lakes and rivers,

$\checkmark$ less chemicals need to be used in the final stage of waste water treatment,

$\checkmark$ less fertilizers need to be used in the agricultural production where waste water is used for irrigation,

$\checkmark$ the qulaity of wetlands can be improved,

$\checkmark$ using waste water for irrigation there is less demand for the use of clean or cleaned water, what is extremly important mainly in case of water scarcity.

The reuse of the terated waste water for irrigation means an additional waste water treatment technology. In this case the irrigated land will work for $u$ sin the last steps of the waste water treatmen so instead of investing into additional technology and using addtitional additional amount of chemicals these extra costs can be spared.On the other hand the nutritions of the waste water will be applied for biomass production by the irrigated plants. So in this way the cost of fertilisers can be spared partly. Additional benefit is that low quality agriculural lands can be used also for this type of irrigation and biomass production int he same time.

One of the goals of the modern and sustainable water management is the recycle of the retained elements (N,P, K).The irrigation with appropriatle treated waste water makes possible to reach this goal also by generating biomass and potentially energy, creating values. This technology is getting more and more valuable in countries where the water scarcity is getting more and more serious due to the consecvencies of climate change.

\section{References and Notes}

[1] FAO 2007: Coping with water scarcity. Letöltve 2016.04.05én a FAO weboldaláról: http://www.fao.org/nr/water/docs/ escarcity.pdf

[2] IPCC Fifth Assessment Report - Climate Change 2013 The Physical Science Basis

[3] Gayer-Ligetvári: Települési vízgazdálkodás, csapadékvíz elhelyezés, AQUAPROFIT Budapest, 2015

[4] World Water DEvelopment Report 2016. Letöltve 2016.04.05-én: http://www.unwater.org/publications/publications-detail/en/c/396246

[5] Press release of the European Commission: http://europa. eu/rapid/press-release_IP-16-827_hu.htm

[6] Veolia Water |The world leader in water services and water treatment) http://www.veoliawater.com.
[7] Dr. Stuart Khan: Drinking water through recycling The benefits and costs of supplying direct to the distribution system Australian Water Recycling Centre of Excellence Report of a study by the Australian Academy of Technological Sciences and Engineering (ATSE), 2013

[8] World Science Forum 2015 - Declaration of the 7th World Science Forum on the Enabling Power of Science, <http://www.sciforum.hu/declaration/index.html>, (letöltés:2015.11.14.)

[9] H. Cooley- K. Donnelly- R. Phurisamban -M. Subramanian: Impacts of California's Ongoing Drought, Agriculture ISBN13: 978-1-893790-66-7, 2015 August Pacific Institute

[10] Prof. Tamás J., Prof. Blaskó L.: Environmental management, Debreceni Egyetem a TÁMOP 4.1.2 pályázat, http:// www.tankonyvtar.hu/hu/tartalom/tamop425/0032_kornyezettechnologia/ch09s02.htm, 2008

[11] Guidelines for Municipal Wastewater Irrigation"Alberta Environment 2000, https://extranet.gov.ab.ca/env/infocentre/ info/library/7268.pdf ISBN 0-7785-1150-2 (On-line edition) 